\title{
OVERTOPPING OF BREAKWATERS WITH A PERMEABLE CREST
}

\author{
Mads Røge Eldrup ${ }^{1}$, Thomas Lykke Andersen'1, Jonas Bjerg Thomsen ${ }^{1}$ and Hans Falk \\ Burcharth $^{1}$
}

\begin{abstract}
In model tests, the wave overtopping discharge is typically measured at the rear corner of the armour crest. So far, all overtopping formulae have been calibrated to predict this specific overtopping discharge. The EurOtop Manual however proposed a formula to include also the discharge trough the permeable armour crests. The total overtopping including the discharge trough the crest armour is relevant in relation to rear armour stability. The discharge trough the armour depends also on the permeability of the core material. In order to study this effect, new model tests were performed with a permeable and an impermeable core. A method for the prediction of the total overtopping discharge is given.
\end{abstract}

Keywords: wave overtopping discharge; relative freeboard; permeable crest

\section{INTRODUCTION}

Wave overtopping on rubble mound breakwaters influences the rear slope stability as well as the safety of operations and installation on and behind the breakwater. The wave overtopping discharge is thus the governing parameter when designing the height of a rubble mound breakwater. The armour freeboard, $A_{\mathrm{c}}$, the crest freeboard, $R_{\mathrm{c}}$, and the crest width, $G_{\mathrm{c}}$, are main structural parameters used in the prediction of the overtopping discharge $q$. The crest freeboard is in the EurOtop Manual by Van der Meer et al. (2016) defined as the height on the structure from where the water can no longer flow back to the seaside, see Fig. 1. This could, for example, be the crown wall freeboard $\left(R_{\mathrm{c}, \text { wall }}\right)$ or the freeboard of an impermeable or only slightly permeable core $\left(R_{\mathrm{c}, \text { core }}\right)$.

The wave overtopping discharge is dependent on where it is measured. Fig. 1 shows three different locations. The discharge caused by wave overtopping is given by $q_{\text {crest, }}$, while the extra discharge through the permeable crest is $q_{\text {armour }}$. Typically, the discharge has been measured only at the armour crest or at the crown wall. In the existing database of overtopping tests, $q_{\text {crest }}+q_{\text {armour }}$ never seems to have been measured for structures without a crown wall. For such cases, reliable estimations of $q_{\text {crest }}+q_{\text {armour }}$ are essential for predictions of the total overtopping volume behind a revetment in order to estimate the needed drainage capacity. Molines et al. (2018) use $q_{\text {crest }}$ to predict the wave loads on crown walls, but this means that if $q_{\text {crest }}=0$ then the forces are also zero. This is clearly not correct as water can still flow in the permeable crest and cause loads on the crown wall. Therefore, it might be better to estimate the wave forces on a crown wall on the basis of $q_{\text {crest }}+q_{\text {armour. This discharge is also relevant for rear slope }}$ stability. The wave overtopping discharge at the armour crest $q_{\text {armour }}$ is the relevant parameter for estimating loads on installations on top of the armour crest and for assessing of operations behind the breakwater.

The EurOtop Manual (Pullen et al., 2007) has recently been updated (Van der Meer et al. 2016). The 2007 version used the crest freeboard, $R_{\mathrm{c}, \text { core }}$ or $R_{\mathrm{c} \text {,wall }}$ to predict the overtopping $q_{\mathrm{crest}}+q_{\mathrm{armour}}$, see Fig. 1 . The second version has for cases without a crown wall changed the procedure to use an average between the armour freeboard, $A_{\mathrm{c}}$ and the core freeboard, $R_{\mathrm{c}, \text { core }}$. They argue that using $A_{\mathrm{c}}$ would provide an underestimation, and using $R_{\mathrm{c}, \text { core }}$ would provide an overestimation of the wave overtopping. This is contradictory to all other formulae that have used $q_{\text {crest }}$. For cases with a crown wall, the second version recommends the use of the maximum of $A_{\mathrm{c}}$ and $R_{\mathrm{c} \text {,wall. }}$ This recommendation is not in line with structures without a crown wall and can lead to underestimations of the overtopping discharge if $A_{\mathrm{c}}$ is larger than $R_{\mathrm{c} \text {,wall }}$ as shown in Fig. 1b. Also, it might lead to strange designs where crown walls are added without any real purpose.

From above is seen that different freeboard recommendations are given in EurOtop for estimating the wave overtopping behind the breakwater $\left(q_{\text {crest }}+q_{\text {armour }}\right)$, but it has not been validated for cases without crown wall. The manual does not provide any guidelines on estimating $q_{\text {crest }}$ which is the important parameter for some overtopping hazards. For example, using the recommendation given by the second version of the EurOtop Manual to design the height of the cross-section shown in Fig. 1a the result would end in a too high structure as the estimation would be for $q_{\text {crest }}+q_{\text {armour }}$ if the design criteria is given as $q_{\text {crest. }}$.

The scope of the present paper is to investigate the validity of the given recommendations in EurOtop for predicting the discharges $q_{\text {crest }}$ and $q_{\text {crest }}+q_{\text {armour }}$ for cross-sections without a crown wall. The paper first presents the recent wave overtopping discharge formulae by Van der Meer et al. (2016) and the

${ }^{1}$ Civil Engineering, Aalborg University, Thomas Manns Vej 23, Aalborg Ø, 9220, Denmark 
modifications made by Eldrup and Lykke Andersen (2018b). After this, a description of the model test setup and the test conditions are given. Finally, the wave overtopping discharge results and related conclusions are presented.

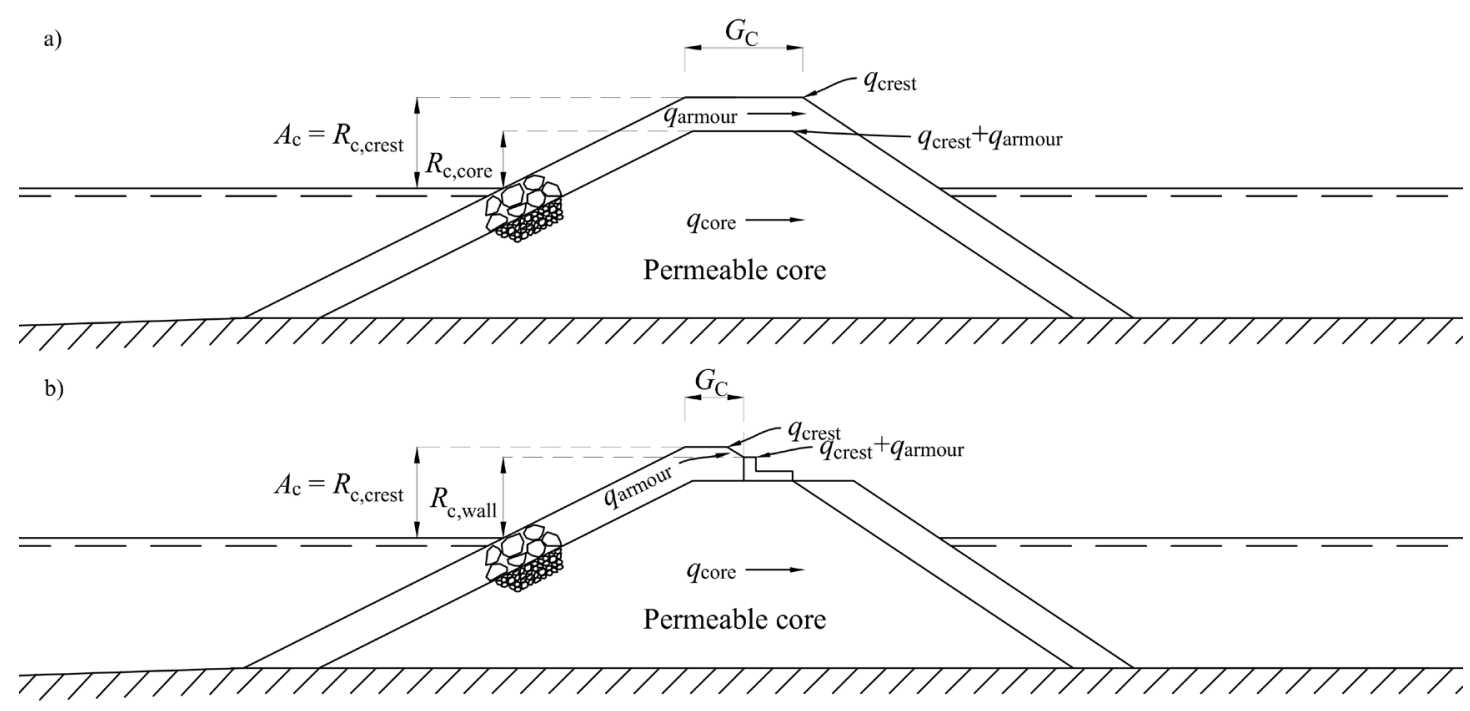

Figure 1. Illustration of armour crest freeboard $A_{\mathrm{c}}$, core freeboard $\boldsymbol{R}_{\mathrm{c}, \text { core, }}$, wall freeboard $\boldsymbol{R}_{\mathrm{c}, \text { wall }}$ and crest width $G_{\mathrm{c}}$. Overtopping discharge passing the crest $q_{\mathrm{crest}}$, trough the permeable crest, $q_{\text {armour }}$ and trough the core, $q_{\mathrm{core}}$.

\section{EUROTOP (2016) AND ELDRUP AND LYKKE ANDERSEN (2018b) MODIFICATION}

In the recent years, a significant increase in the reliability of formulae for predicting wave overtopping discharges for surging waves is seen. The first version of the EurOtop Manual (Pullen et al., 2007) used a constant roughness factor, $\gamma_{\mathrm{f}}$. Christensen et al. (2014) showed that the roughness factor was dependent on the breaker parameter, $\xi_{\mathrm{m}-1,0}$. They used a varying roughness factor, $\gamma_{\mathrm{fsurging}}$, that was already defined in the EurOtop Manual, but only used in relation to wave run-up. This varying roughness factor increases the roughness factor for $\xi_{\mathrm{m}-1,0}>1.8$, thus indicating that the dissipation on the slope is reduced in surging waves compared to plunging waves. This change significantly improved the reliability of the predictions, especially for low steepness waves. The second edition of the EurOtop Manual (Van der Meer et al., 2016) included a different varying roughness factor, $\gamma_{\mathrm{fmod}}$, but this factor only influenced predictions for $\xi_{\mathrm{m}-1,0}>5$ although only based on data by Bruce et al. (2009) consisting of $\xi_{\mathrm{m}-1,0}$ in the range 2.8 - 4.5. The data by Bruce et al. (2009) was initially used to estimate $\gamma_{\mathrm{f}}$ for different armour units. Eldrup and Lykke Andersen (2018b) refitted $\gamma_{\mathrm{f}}$, but with use of $\gamma_{\mathrm{fsurging}}$ based on the tests by Bruce et al. (2009), Christensen et al. (2014) and their own data.

The Eurotop Manual includes the crest width reduction factor, $C_{\mathrm{r}}$, by Besley (1999). The manual states that the crest width reduction factor should only be used if the crest width is larger than three armour units. Eldrup and Lykke Andersen (2018b) found that the reliability of the predictions was further increased if the crest reduction factor was used for all cases. However, their conclusion was based on data with a limited variation in the crest width, the main part having a crest width of approximately three armour units. Thus, it still remains to be examined if the reduction factor by Besley (1999) is valid for wider crests and low steepness waves. The formulation for wave overtopping discharge by Van der Meer et al. (2016) is shown in Eq. 1. 


$$
\frac{q}{\sqrt{g H_{\mathrm{m} 0}^{3}}}=\frac{0.023}{\sqrt{\tan \alpha}} \gamma_{\mathrm{b} \xi_{\mathrm{m}}-1,0} \exp \left(-\left(2.7 \frac{R_{\mathrm{c}}}{\xi_{\mathrm{m}-1,0} H_{\mathrm{m} 0} \gamma_{\mathrm{b}} \gamma_{\mathrm{fmod}} \gamma_{\beta} \gamma_{\mathrm{v}}}\right)^{1.3}\right) C_{\mathrm{r}}
$$

With a maximum of

$$
\frac{q}{\sqrt{g H_{\mathrm{m} 0}^{3}}}=0.09 \exp \left(-\left(1.5 \frac{R_{\mathrm{c}}}{H_{\mathrm{m} 0} \gamma_{\text {fmod }} \gamma_{\beta} \gamma^{*}}\right)^{1.3}\right) C_{\mathrm{r}}
$$

Crest width reduction factor

$$
C_{\mathrm{r}}=\left\{\begin{array}{lr}
1 & G_{\mathrm{c}} / D_{\mathrm{n} 50} \leq 3 \text { or } G_{\mathrm{c}} / H_{\mathrm{m} 0}<0.75 \\
3.06 \exp \left(-\frac{1.5 G_{\mathrm{c}}}{H_{\mathrm{m} 0}}\right) & \text { otherwise }
\end{array}\right.
$$

Varying roughness factor

$$
\gamma_{\text {fmod }}=\left\{\begin{array}{lc}
\gamma_{\mathrm{f}} & \xi_{\mathrm{m}-1,0} \leq 5 \\
\gamma_{\mathrm{f}}+\frac{\left(\xi_{\mathrm{m}-1,0}-5\right)\left(1-\gamma_{\mathrm{f}}\right)}{5} & \xi_{\mathrm{m}-1,0}>5 \\
1 & \xi_{\mathrm{m}-1,0}>10
\end{array}\right.
$$

where $\gamma_{b}$ is the reduction factor for a berm, $\gamma_{\beta}$ is the reduction factor for wave obliquity. $\gamma_{\mathrm{v}}$ is the reduction factor for a wall at the end of the slope and $\gamma^{*}$ is the reduction factor for a storm wall on a slope or promenade for non-breaking waves.

The formulation by Eldrup and Lykke Andersen is shown in Eq. 2.

$$
\frac{q}{\sqrt{g H_{\mathrm{m} 0}^{3}}}=\frac{0.023}{\sqrt{\tan \alpha}} \gamma_{\mathrm{b} \xi_{\mathrm{m}}-1,0} \exp \left(-\left(2.7 \frac{R_{\mathrm{c}}}{\xi_{\mathrm{m}-1,0} H_{\mathrm{m} 0} \gamma_{\mathrm{b}} \gamma_{\text {fsurging }} \gamma_{\beta} \gamma_{\mathrm{v}}}\right)^{1.3}\right) C_{\mathrm{r}}
$$

With a maximum of

$$
\frac{q}{\sqrt{g H_{\mathrm{m} 0}^{3}}}=0.09 \exp \left(-\left(1.5 \frac{R_{\mathrm{c}}}{H_{\mathrm{m} 0} \gamma_{\text {fsurging }} \gamma_{\beta} \gamma^{*}}\right)^{1.3}\right) C_{\mathrm{r}}
$$

Crest width reduction factor

$$
C_{\mathrm{r}}=\left\{\begin{array}{lr}
1 & G_{\mathrm{c}} / H_{\mathrm{m} 0}<0.75 \\
3.06 \exp \left(-\frac{1.5 G_{\mathrm{c}}}{H_{\mathrm{m} 0}}\right) & \text { otherwise }
\end{array}\right.
$$

Varying roughness factor

$$
\gamma_{\text {fsurging }}= \begin{cases}\gamma_{\mathrm{f}} & \xi_{\mathrm{m}-1,0} \leq 1.8 \\ \gamma_{\mathrm{f}}+\frac{\left(\xi_{\mathrm{m}-1,0}-1.8\right)\left(1-\gamma_{\mathrm{f}}\right)}{8.2} & \xi_{\mathrm{m}-1,0}>1.8 \\ 1 & \xi_{\mathrm{m}-1,0}>10\end{cases}
$$

Eldrup and Lykke Andersen (2018b) used only data with $q_{\text {crest }}$ and defined the freeboard to be used in the formula as the maximum of $A_{\mathrm{c}}$ and $R_{\mathrm{c}}$. Most of the data had however $R_{\mathrm{c} \text {,wall }}=A_{\mathrm{c}}$. Fig. 2 shows the data by Bruce et al. (2009). The middle part of the figure shows that the scatter is slightly reduced when using $\gamma_{\text {fsurging }}$ as proposed by Christensen et al. (2014) compared to the use of $\gamma_{\text {fmod }}$ as shown in the top part of the figure. This shows that even for $\xi_{\mathrm{m}-1,0}$ in the range $2.8-4.5$ there is an improvement when using $\gamma_{\text {fsurging }}$ instead of $\gamma_{\text {fmod. }}$. Christensen et al. (2014) is though overestimating the wave overtopping 
discharge and therefore a refit of the $\gamma_{\mathrm{f}}$ was performed by Eldrup and Lykke Andersen (2018b) seen in the lower part of the figure. Note that Eldrup and Lykke Andersen (2018b) used the crest width reduction factor $C_{\mathrm{r}}$ in all cases.
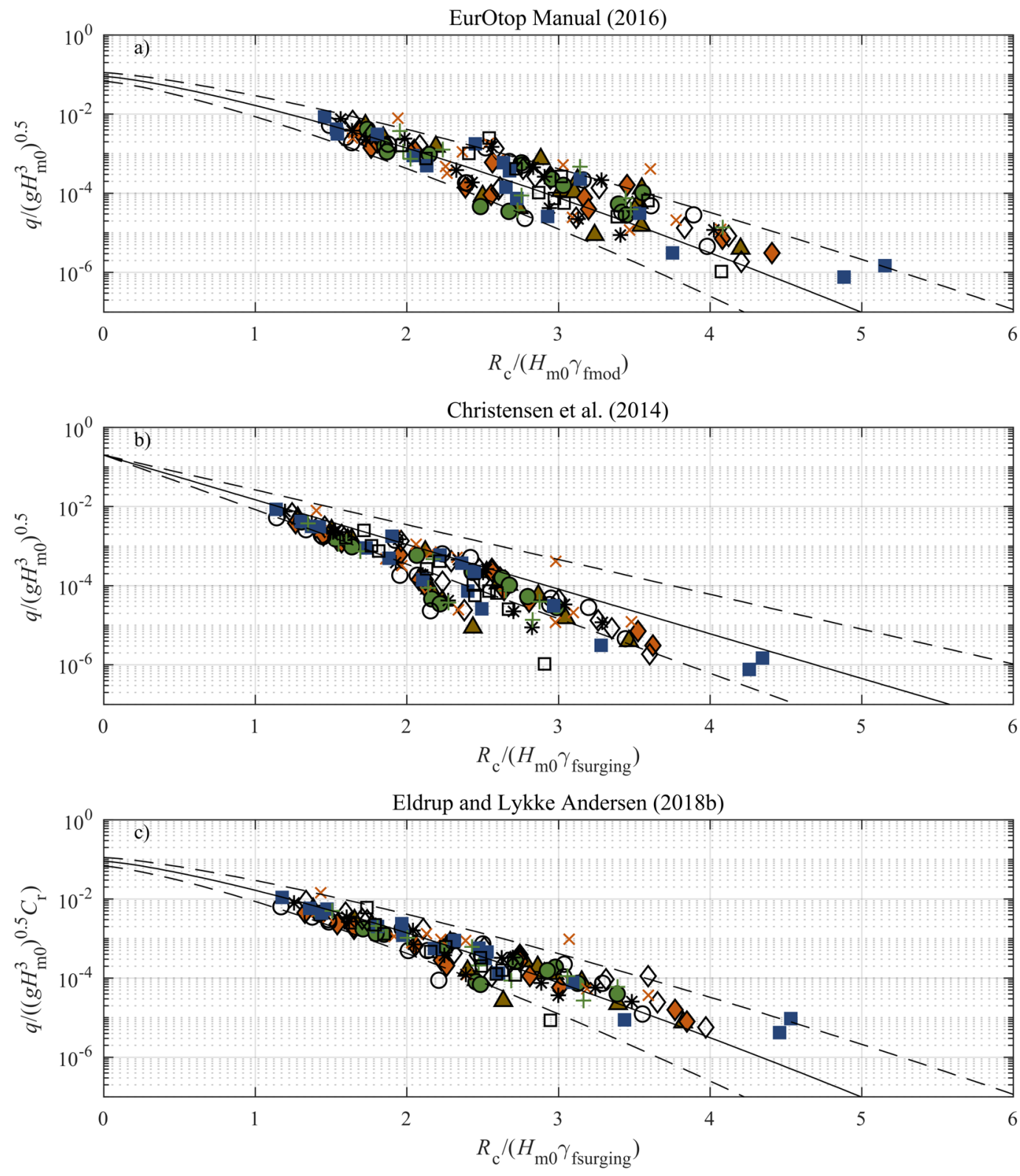

\begin{tabular}{|llllllllll|}
\hline$\Delta$ & Coreloc & 0 & Xbloc & $\diamond$ & Cube rough & $*$ & Haro & + & Tetrapod \\
$\diamond$ & Accropode & 0 & Cube flat & $\times$ & Anitfer & $\square$ & Cube 1-layer & $\square$ & Rock \\
\hline
\end{tabular}

Figure 2. Comparison between different varying roughness factors with the data by Bruce et al. (2009). (a) shows the approach by EurOtop (2016), (b) Christensen et al. (2014) and (c) Eldrup and Lykke Andersen (2018b). The continuous line shows the mean value approach and the dashed lines shows the $90 \%$ confidence band.

The present test programme included steep and low steepness waves. Therefore, the formulation given by Eldrup and Lykke Andersen (2018b) is used for comparison with the present results. It is investigated which freeboard height should be used for predicting wave overtopping at the armour crest $\left(q_{\text {crest }}\right)$ and at the core freeboard $\left(q_{\text {crest }}+q_{\text {armour }}\right)$. 


\section{MODEL TEST SETUP AND TEST CONDITIONS}

The present study includes new model tests performed in the wave flume at Aalborg University with dimensions of $18.2 \mathrm{~m} \times 1.5 \mathrm{~m} \times 1.5 \mathrm{~m}(1 \times \mathrm{w} \times \mathrm{h})$. The floor was horizontal for the first two meters in front of the wavemaker followed by a 1:30 foreshore to the toe of the breakwater, see Fig. 3 .

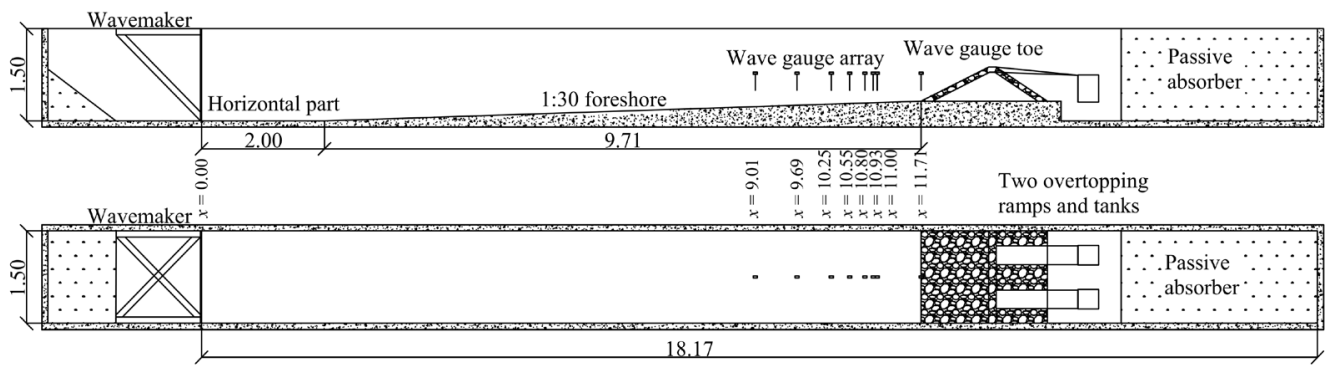

Figure 3. Flume setup.

Wave gauges were placed in front of the breakwater in order to separate waves into incident and reflected waves. The wave separation method by Eldrup and Lykke Andersen (2019) was used, which is a nonlinear method that separates the wave components not only into incident and reflected components but also into free and bound components. The method has on mild foreshore slopes shown to be reliable for the entire interval from linear to highly nonlinear waves. The waves were also measured without the structure in place, and an additional wave gauge was placed at the toe of the structure. The incident waves with the structure in place and the total waves without the structure were almost identical in the wave gauge array. However, due to the relatively steep foreshore, the waves might change significantly from the array to the toe of the structure either due to shoaling or to wave breaking. Comparing the total waves without the structure for wave gauge, $x=11.00$ with the wave gauge at $x=11.71$ (cf. Fig. 3 ), an increase in wave height is seen for all tests with a maximum increase of $7 \%$. Therefore, the wave data measured by the wave gauge at $x=11.71$ without the structure in place, is used for the following analysis in this paper.

The waves were generated with a piston-type wavemaker which was controlled by the AwaSys (2018) software. The waves were generated with a JONSWAP spectrum with a peak enhancement factor of $\gamma=$ 3.3. Due to the generation of nonlinear waves in the present tests, the guidelines on the applicability of wavemaker theories given by Eldrup and Lykke Andersen (2018a) was followed. For the mildly nonlinear cases, second-order theory was used $(S<2)$, but for the highly nonlinear case $(S>2)$, the Zhang et al. (2007) method was used. The method by Zhang uses the surface elevation and the depth-averaged velocity as input, which was calculated with the Celeris Boussinesq wave model by Tavakkol and Lynett (2017). Both wavemaker methods are implemented in AwaSys (2018). The active wave absorption by Lykke Andersen et al. (2016) was used in the present tests, which has shown to have good performance for linear and nonlinear waves, cf. Lykke Andersen et al. (2018).

One cross-section with a permeable core, and one with an impermeable core were tested, cf. Fig. 4. Two overtopping ramps of $0.3 \mathrm{~m}$ width were installed, one at the armour rear crest shoulder and one at the core rear crest shoulder. The ramp located at the core crest had a protective net to prevent rocks from sliding into the overtopping tank. The water depth, $h$, at the toe of the structure was $37 \mathrm{~cm}$, and $A_{\mathrm{c}}$ was $18 \mathrm{~cm}$ in all tests. For the cross-section with a permeable core, the core freeboard was $R_{\mathrm{c}, \text { core }}=9.6 \mathrm{~cm}$ and for the impermeable core it was $R_{\mathrm{c}, \text { core }}=7.5 \mathrm{~cm}$. The core material had $D_{\mathrm{n} 50}=1.5 \mathrm{~cm}$ and gradation $D_{\mathrm{n} 85} / D_{\mathrm{n} 15}=1.36$. The spectral significant wave height $\left(H_{\mathrm{m} 0}\right)$ varied between $9 \mathrm{~cm}$ and $11 \mathrm{~cm}$. The choice of model core material size might be motivated as follows: if for example the length scale of the applied model is $1: 30$, the prototype $H_{\mathrm{m} 0} \approx 3 \mathrm{~m}$ and the core material can be characterised by $D_{\mathrm{n} 50}=26 \mathrm{~cm}$ and $n=0.38$, a characteristic pore velocity will be approximately $7 \mathrm{~cm} / \mathrm{s}$, see Burcharth et al. (1999). If compensating for viscous scale effects the core material should, if well narrow graded, have a $D_{\mathrm{n} 50}=$ $0.14 \mathrm{~cm}$. The actually used core material in the model had $D_{\mathrm{n} 50}=0.15 \mathrm{~cm}$, i.e. very close to the estimated $D_{\text {n50 }}=0.14 \mathrm{~cm}$. Thus, the scaling of the core material seems realistic. 

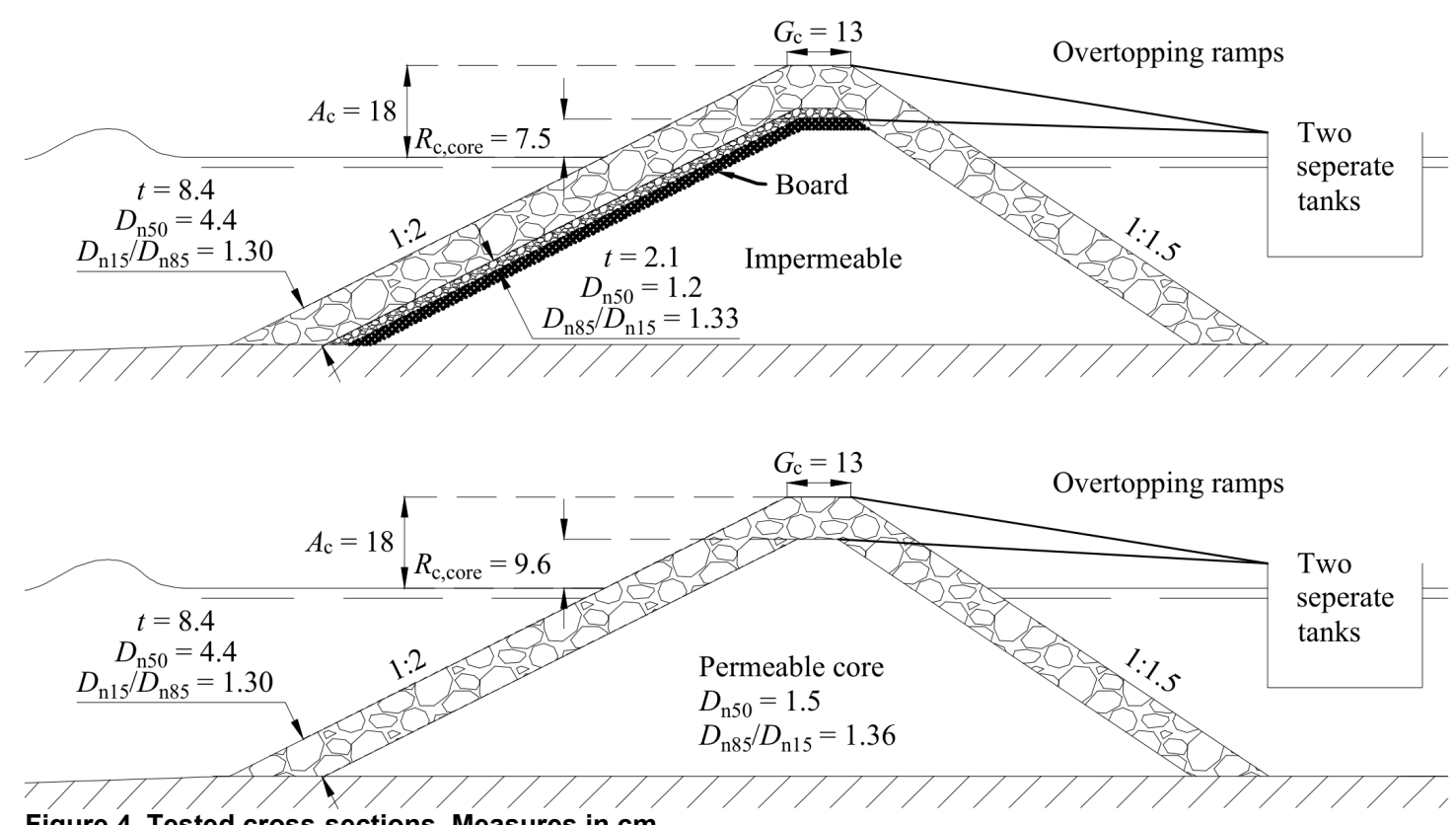

Figure 4. Tested cross-sections. Measures in $\mathrm{cm}$.

Six sea states with identical wave steering signals were used in the present study for both crosssections. Thus, 12 tests were performed in total. The tested ranges are shown in Table 1.

\begin{tabular}{|l|l|}
\hline \multicolumn{2}{|c|}{ Table 1. Test ranges. } \\
\hline$R_{\mathrm{d}} / H_{\mathrm{m} 0}$ & $0.90-1.11$ \\
$A_{\mathrm{d}} H_{\mathrm{m} 0}$ & $1.68-2.09$ \\
$\mathrm{G}_{\mathrm{d}} / H_{\mathrm{m} 0}$ & $1.18-1.46$ \\
$H_{\mathrm{m} 0} / h$ & $0.23-0.29$ \\
$\xi_{\mathrm{m}-1,0}$ & $2.58-6.71$ \\
\hline
\end{tabular}

\section{OVERTOPPING RESULTS}

Fig. 5 shows a comparison between the measured wave overtopping discharge $q_{\text {crest }}$ and $q_{\text {crest }}+q_{\text {armour }}$ for the permeable and impermeable breakwater. The figure shows which proportion of the overtopping discharge (ex. discharge through the core) goes through the armour layer in the two models with permeable and impermeable cores. The proportion is much higher in the case of the impermeable core. However, the two cases permeable and impermeable are not directly comparable because the core freeboard $R_{\text {c,core }}$ is $9.6 \mathrm{~cm}$ and $7.5 \mathrm{~cm}$, respectively. Also, the discharge through the core in the model with permeable core is unknown. Even so, a relatively much higher discharge seems to go through the armour layer in the case of the impermeable core, actually a factor of up to 15 as compared to a factor of four. The results show that there is a clear difference in measured overtopping discharge at the armour crest $\left(q_{\text {crest }}\right)$ and at the core $\left(q_{\text {crest }}+q_{\text {armour }}\right)$. This is especially the case when the core is impermeable and therefore hinder infiltration from the permeable crest into the core. Thus, more water will reach the overtopping tank connected to the core shoulder. 

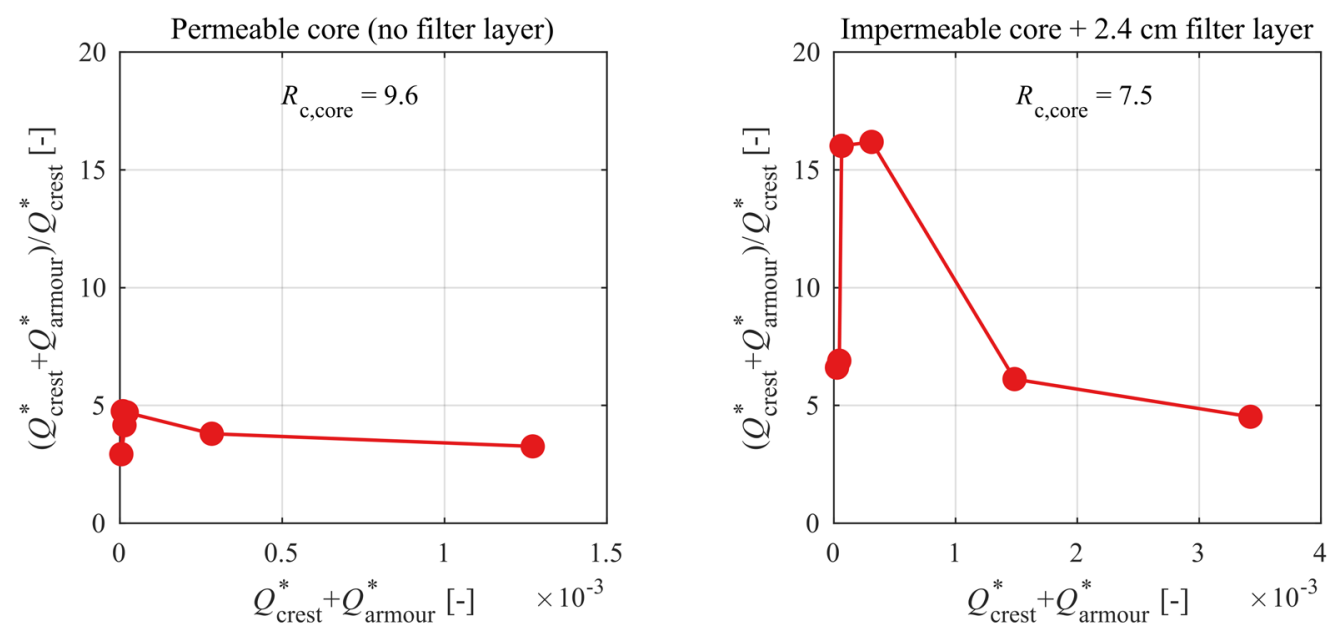

Figure 5. Comparison of measured dimensionless overtopping discharge at the armour crest and the core crest, $Q^{*}=q /\left(g H_{m 0}\right)^{0.5}$

\section{COMPARISON OF EUROTOP RECOMMENDATIONS FOR DISCHARGE TROUGH ARMOUR}

The previously discussed recommendations given in the EurOtop manual for the predictions of the wave overtopping discharge through the permeable armour layer is tested. The recommendations are tested against the wave overtopping discharge measured on the armour crest level ( $\left.q_{\text {crest }}\right)$ for the permeable and impermeable cross-sections, see Fig. 6 . The continuous line illustrates the predicted wave overtopping discharge with use of the formulae (2) by Eldrup and Lykke Andersen (2018b) and the dashed lines shows the $90 \%$ confidence band. Using a relative freeboard $R^{*}=A_{\mathrm{c}} /\left(H_{\mathrm{mo}} \gamma_{\text {fsurging }}\right)$ in the formulae (2), the predictions fit well with the measured overtopping discharge with all the data inside the $90 \%$ confidence band. Like all other overtopping formulae, formulae (2) predicts an increase in discharge with a decrease in the freeboard. Therefore, if using the lower relative freeboard by Pullen et al. (2007) $\left(R^{*}=R_{\mathrm{c}} /\left(H_{\mathrm{m} 0} \gamma_{\text {surging }}\right)\right)$ the overtopping discharge is overestimated when using the tested formulae (2). Similarly, when using the relative freeboard recommended by Van der Meer et al. (2016) $\left(R^{*}=\left(A_{\mathrm{c}}+R_{\mathrm{c}}\right) /\left(2 H_{\mathrm{m} 0} \gamma_{\mathrm{fsurging}}\right)\right)$ in (2) the overtopping discharge is also overestimated, however to a lesser degree. Based on the test results, it can be concluded that $A_{\mathrm{c}}$ should be used as the freeboard for estimating the wave overtopping discharge $q_{\text {crest }}$ for cases without a crown wall. 


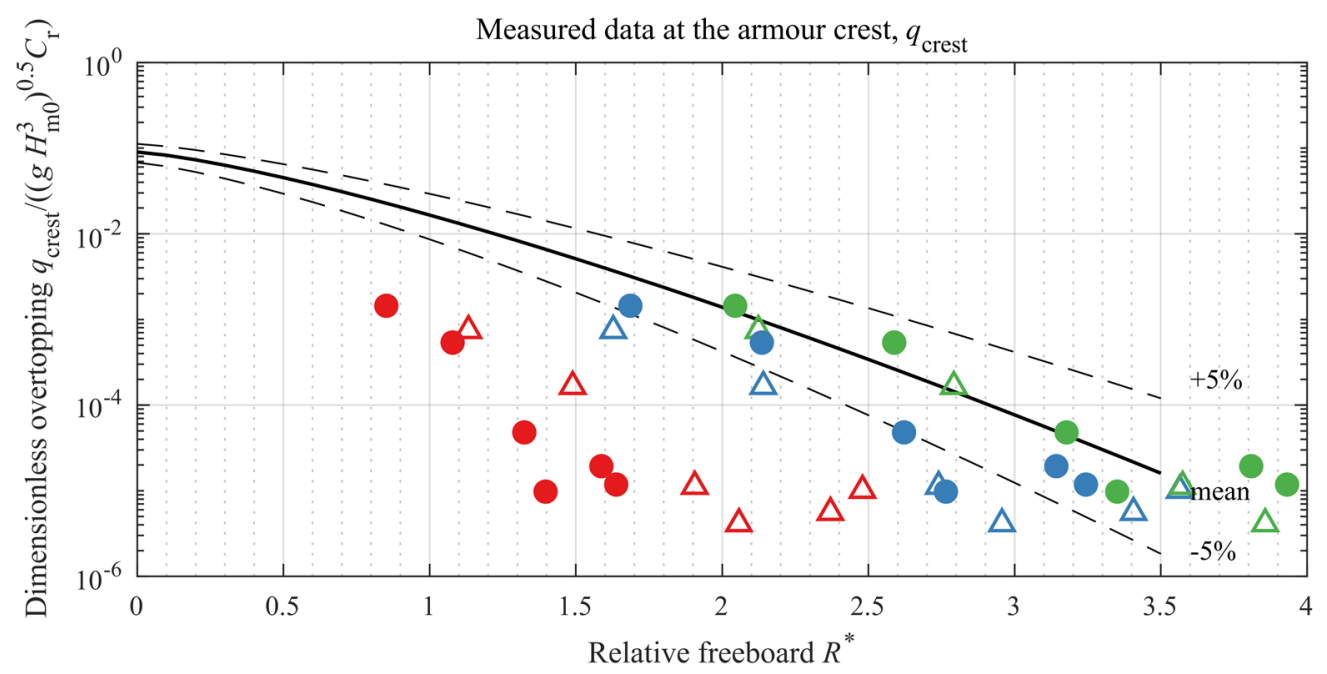

\begin{tabular}{|lll|}
\hline Pullen et al. (2007): $R^{*}=R_{\mathrm{c}, \mathrm{core}} /\left(H_{\mathrm{m} 0} \gamma_{\text {fsurging }}\right)$ & Permeable & Impermeable $\Delta$ \\
Van der Meer et al. (2017): $R^{*}=\left(A_{\mathrm{c}}+R_{\mathrm{c}, \mathrm{core}}\right) /\left(2 H_{\mathrm{m} 0} \gamma_{\text {fsurging }}\right)$ & Permeable & Impermeable $\Delta$ \\
Present proposal: $R^{*}=A_{\mathrm{c}} /\left(H_{\mathrm{m} 0} \gamma_{\text {fsurging }}\right)$ & Permeable & Impermeable $\Delta$
\end{tabular}

Figure 6. Comparison between measured and predicted overtopping discharge with different dimensionless freeboard definitions. Data is for the measurements on top of the armour crest. The continuous line shows the predicted wave overtopping discharge by Eldrup and Lykke Andersen (2018b), and the dashed lines show the $90 \%$ confidence band.

Fig. 7 shows the wave overtopping measured at the core $\left(q_{\text {crest }}+q_{\text {armour }}\right)$. Using $A_{\mathrm{c}}$ as the freeboard in the formulae, slightly smaller values of the wave overtopping discharge are estimated compared to the measured discharge. Using the definition by Van der Meer et al. (2016), the data is well predicted by (2) with all data inside the $90 \%$ confidence band. It should be noted that the formulae provide slightly larger overtopping values for the tests with an impermeable core and slightly smaller values with a permeable core. Using the freeboard definition by Pullen et al. (2007) in the formulae (2), significantly larger wave overtopping discharges are estimated at the core rear shoulder $\left(q_{\text {crest }}+q_{\text {armour }}\right)$. From the present tests, the freeboard recommendation given by Van der Meer et al. (2016) seems to be valid when predicting wave overtopping discharge $q_{\text {crest }}+q_{\text {armour }}$ by formulae (2) even though they did not have tests to validate it.

There is a clear separation of the results for the impermeable and the permeable core when estimating the wave overtopping discharge at the core. More tests with permeable and impermeable cores are needed in order to investigate the influence from the core permeability on the discharge $q_{\text {crest }}+q_{\text {armour }}$. Furthermore, an even larger difference between $q_{\text {crest }}+q_{\text {armour }}$ and $q_{\text {armour }}$ is expected for wider crests than tested which is not included in the crest width reduction factor by Besley (1999). 


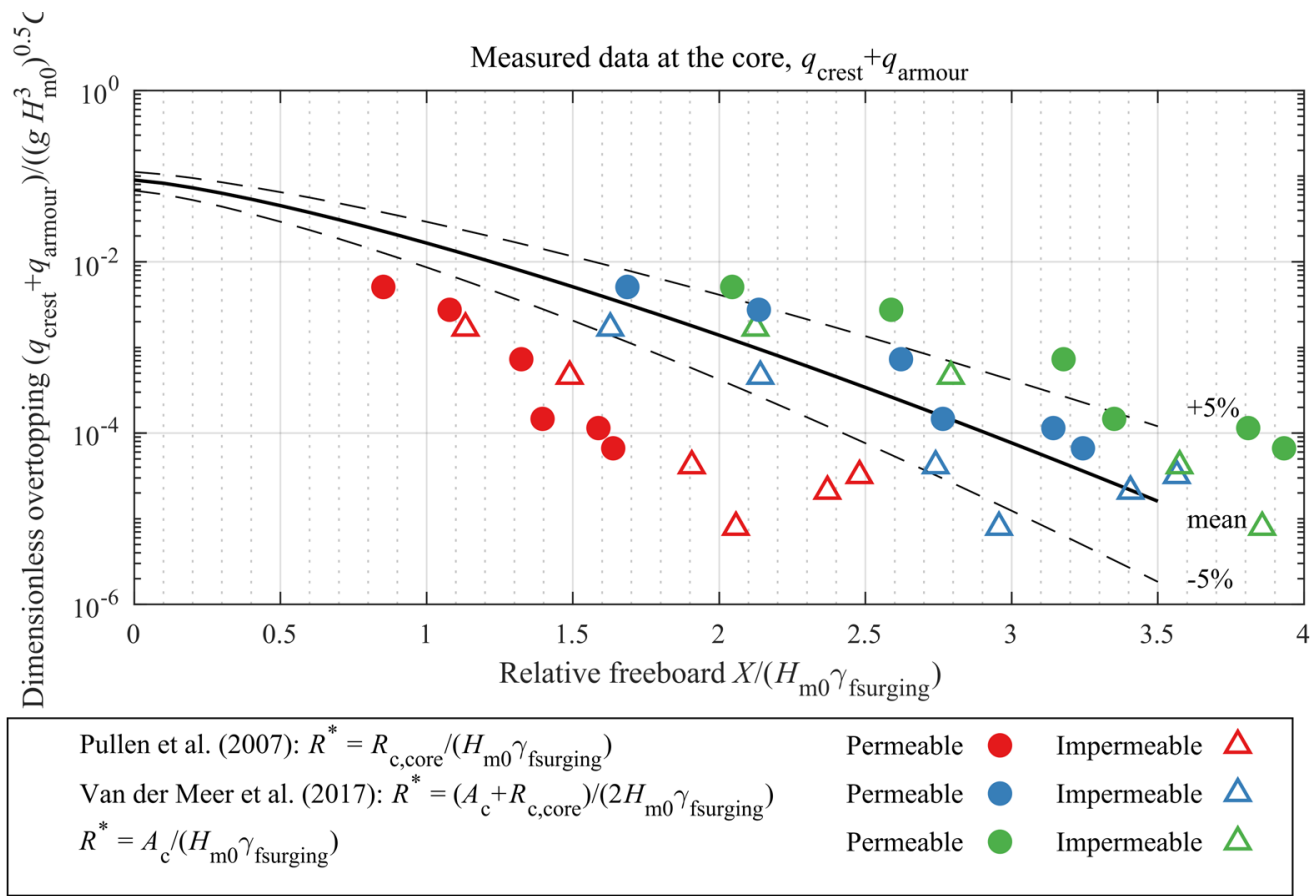

Figure 7. Comparison between measured and predicted overtopping discharge with different dimensionless freeboard definitions. Data is for the measurements on top of the core. The continuous line shows the predicted wave overtopping discharge by Eldrup and Lykke Andersen (2018b), and the dashed lines show the $90 \%$ confidence band.

\section{DISCUSSION}

New model tests with measurements of wave overtopping discharge at the rear shoulder of the armour crest and the core crests were made. Models with permeable and impermeable core were used. The results showed that in the model with impermeable core, relatively much larger discharges through the armour layer took place than in the model with permeable core. The results also showed that reliable predictions of the discharge over the armour crest plus the discharge through the armour layer can be obtained when using $\left(A_{\mathrm{c}}+R_{\mathrm{c}, \text { core }}\right) / 2$ as the relative freeboard in the formula by Eldrup and Lykke Andersen (2018b). Furthermore, the results showed that the discharge overtopping the armour crest could be estimated by using $A_{\mathrm{c}}$ as freeboard in the formula by Eldrup and Lykke Andersen (2018b).

Recommendations given in the first and the second editions of the EurOtop Manual with respect to the relative freeboard in wave overtopping predictions are discussed. The manual recommends only one value for estimation of the wave overtopping, while the present paper recommends more freeboards to be used dependent on the failure mode under investigation. For example, installations on top of the armour crest are only exposed to discharges over the armour crest, while the rear slope is also exposed to the discharge through the armour layer.

As the present research included a limited number of tests more tests should be performed in order to verify the recommendation for relative freeboard in prediction of overtopping discharges through the armour layer. Furthermore, it is recommended to study the influence of the discharge on the rear slope stability.

\section{REFERENCES}

Besley, P. 1999. Overtopping of seawalls - design and assessment manual, $R \& D$ Technical Report $W$ 178, Environment Agency, Bristol, ISBN 1-85705-069-X.

Bruce, T., Van der Meer, J.W., Franco, L., and Pearson, J.M. 2009. Overtopping performance of different armour units for rubble mound breakwaters, Coastal Engineering, 56, pp. 166-179.

Burcharth, H.F., Liu, Z., and Troch, P. 1999. Scaling of Core Material in Rubble Mound Breakwater Model Tests, Fifth International Conference on Coastal and Port Engineering in Developing Countries, COPEDEC, Cape Town, pp. 1518-1528.

Christensen, N.F., Røge, M.S., Thomsen, J.B., Lykke Andersen, T., Burcharth, H.F., and Nørgaard, J.Q.H. 2014. Overtopping on rubble mound breakwaters for low steepness waves in deep and depth limited conditions, Coastal Engineering Proceedings, 34. 
Eldrup, M.R., and Lykke Andersen T. 2018a. Applicability of Nonlinear Wavemaker Theory. Proceedings of the 7th International Conference on the Application of Physical Modelling in Coastal and Port Engineering and Science, Santander, Spain.

Eldrup, M.R., and Lykke Andersen T. 2018b. Recalibration of Overtopping Roughness Factors of Different Armour Types. The $11^{\text {th }}$ Coasts, Marine Structures and Breakwaters Conference, ISBN 978-0-7277-6317-4, pp. 1011-1020.

Eldrup, M.R., and Lykke Andersen T. 2019. Estimation of Incident and Reflected Wave Trains in Highly Nonlinear Two-Dimensional Irregular Waves, Journal of Waterway, Port, Coastal, and Ocean Engineering, Volume 145, Issue 1.

EurOtop, 2007. European Manual for the Assessment of Wave Overtopping. Pullen, T., Allsop, N.W.H., Bruce, T., Kortenhaus, A., Schüttrumpf, H., and Van der Meer, J.W., At: www.overtoppingmanual.com

EurOtop, 2016. Manual on wave overtopping of sea defences and related structures. An overtopping

manual largely based on European research, but for worldwide application. Van der Meer, J.W., Allsop, N.W.H., Bruce, T., De Rouck, J., Korenhaus, A., Pullen, T., Schüttrumpf, H., Troch, P., and Zanuttigh, B., www.overtoppingmanual.com

Lykke Andersen, T., Clavero, M., Frigaard, P., Losada, M., Puyol, J.I. 2016. A New Active Absorption System and its Performance to Linear and Non-linear Waves. Coastal Engineering, 114, pp. 47-60.

Lykke Andersen, T., Clavero, M., Eldrup, M.R., Frigaard, P., Losada, M., 2018. Active Absorption of Nonlinear Irregular Waves. Coastal Engineering Proceedings, 36.

Molines, J., Herrera, M.P., and Medina, J.R., 2018. Estimations of Wave Forces on Crown Walls Based on Wave Overtopping Rates. Coastal Engineering, 132, pp. 50-62.

Tavakkol, Sasan, and Patrick Lynett, 2017. Celeris: A GPU-accelerated open source software with a Boussinesq-type wave solver for real-time interactive simulation and visualization, Computer Physics Communications, 217, pp. 117-127.

Zhang, H., Schäffer, H.A., and Jakobsen, K. P. 2007. Deterministic combination of numerical and physical coastal wave models, Coastal Engineering, 54, pp. 171-186. 